\title{
Thermal Analysis of some Imidazolinone Derivatives
}

\author{
Shipra Baluja*, Nikunj Kachhadia \\ Department of Chemistry, Saurashtra University, Rajkot - 360 005, Gujarat India \\ *E-mail address: shipra_baluja@rediffmail.com
}

\begin{abstract}
Thermal analysis of some imidazolinone derivatives derived from 1, N-phenyl-3-p-nitrophenyl4-formyl pyrazole, have been carried out by TGA technique. From these thermograms, various kinetic parameters such as order of degradation (n), energy of activation (E), frequency factor (A) and entropy change $(\Delta S)$ have been evaluated. Further, thermal stability of imidazolinone derivatives have been determined, which is found to depend on the type of substituent present in the compounds.
\end{abstract}

Keywords: imidazolinone derivatives; physical and chemical properties; pharmaceutical industry

\section{INTRODUCTION}

Thermal analysis has become an established method to study the thermal behavior of materials and finds wide applications in diverse industrial and research fields. It has been used to determine the physical and chemical properties of various compounds, polymers, geological materials and coals ${ }^{(1-7)}$. Further, various reversible and non-reversible reactions ${ }^{(8,9)}$, the decomposition of molecules absorbed on a surface, phase transitions etc. can also be studied. Several investigations have been carried out on the application of thermal methods in pharmaceutical industry ${ }^{(10-15)}$.

In present paper, thermal properties of some imidazolinone derivatives have been studied by using TGA technique.

\section{EXPERIMENTAL}

\subsection{Materials}

Most of the chemicals used were of analytical grade, while the solvents were purified and double distilled before use. 


\subsection{Preparation of Imidazolinone derivatives}

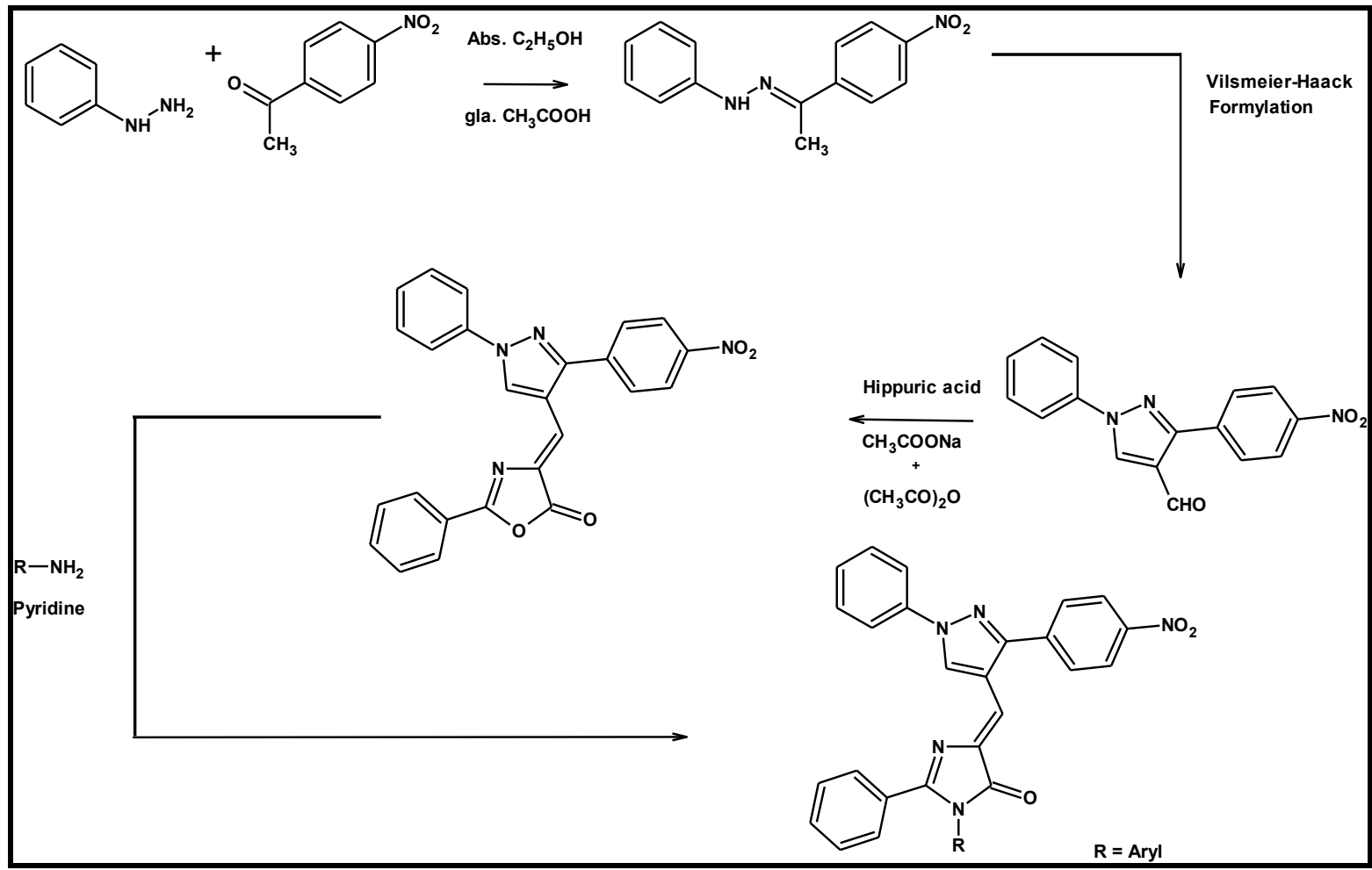

Reaction Scheme

\subsection{Instrumentation}

The Thermo gravimetric analysis (TGA) measurements were made on the instrument "Universal V2.6D TA Instrument" at the heating rate of $10^{\circ} \mathrm{C}$ per minute in nitrogen atmosphere for imidazolinone derivatives.

\section{RESULTS AND DISCUSSION}

Various physical constants of imidazolinone derivatives are given in Table 1.

Thermogram of only one compound PAIM-1 is shown in Figure 1. It is observed from thermograms that except PAIM-4 and PAIM-9, all the derivatives degrade in more than one step and each step is of different order. The variation in the trend of thermal decomposition might be interpreted by taking into account some intermolecular interactions (structural as well as electronic) and also because of several experimental factors.

Further, various thermal properties such as initial decomposition temperature (IDT), the decomposition temperature range and the maximum degradation along with the percentage weight loss and Exo / Endo transitions of all the imidazolinone derivatives are evaluated from the thermograms and are reported in Table 2. It is observed from Table 2 that PAIM-4 is most stable whereas PAIM-8 is less stable. This suggests that the presence of 1-napthylamine (as in PAIM-4) causes greater stability than 3-Cl-4-F-aniline (as in PAIM-8), which is less stable.

Further, various kinetic parameters, such as order of the degradation (n), energy of activation (E), frequency factor (A) and entropy change $(\Delta S)$ for each step are calculated by 
Anderson-Freeman method ${ }^{(16)}$ and Horowitz and Metzger ${ }^{(17)}$ method and are given in Tables 3 and 4.

It is evident from Tables 3 and 4 that order of reaction is quite different in different steps for different imidazolinone derivatives. For first step, order of reaction varies from 2.5 to 21. For second step also, values of $n$ varies from 2.5 to 6.7 .

In first step, energy of activation (E) is maximum for PAIM-5 and minimum for PAIM4. The frequency factor (A) also varies in the same order i.e., maximum for PAIM-5 and minimum for PAIM-4. In second step, energy of activation is found to be maximum for PAIM-3 and minimum for PAIM-6. The frequency factor $\mathrm{A}$ is also maximum for PAIM-3 and minimum for PAIM-6. Comparison of E and A values in Tables 3 and 4 shows that the values of $\mathrm{E}$ and $\mathrm{A}$ are minimum for second steps of all the imidazolinone derivatives.

Further, change in entropy $\left(\Delta \mathrm{S}^{\circ}\right)$ for all these reactions were also calculated by equation (7). It is observed that the change in entropy are positive for all the compounds except PAIM-4 and PAIM-9 for the first step while in second step, entropy changes are negative for all the imidazolinone derivatives. The positive $\Delta \mathrm{S}^{\circ}$ indicates that the transition state is in less ordered state. Whereas the negative $\Delta \mathrm{S}^{\circ}$ values indicate that the activation complex has a more ordered or more rigid structure than the reactants and the reaction is slower than the normal $^{(18)}$.

Thus, the degradation in imidazolinone derivatives is multi step process with different order of reaction. Further, thermal stability depends upon the type of substituent present. It is observed that presence of 1-napthylamine (as in PAIM-4) increases the stability whereas 3Cl-4-F-aniline (as in PAIM-8) decreases the stability.

\section{Acknowledgement}

Authors are thankful to Head of Chemistry Department for providing necessary facilities.

Table 1. Physical constants of Imidazolinones.

\begin{tabular}{|c|c|c|c|c|c|c|c|}
\hline $\begin{array}{l}\text { Sr. } \\
\text { No. }\end{array}$ & Code & $\mathbf{R}$ & M.F. & $\begin{array}{l}\text { M. Wt. } \\
\text { (g/mol) }\end{array}$ & $\begin{array}{c}\mathbf{R}_{\mathbf{f}}^{*} \\
\text { Value }\end{array}$ & $\begin{array}{c}\text { M.P. } \\
{ }^{\circ} \mathrm{C} \\
\end{array}$ & $\begin{array}{c}\text { Yield } \\
\%\end{array}$ \\
\hline 1. & PAIM-1 & $4-\mathrm{CH}_{3}-\mathrm{C}_{6} \mathrm{H}_{4}-$ & $\mathrm{C}_{32} \mathrm{H}_{23} \mathrm{O}_{3} \mathrm{~N}_{5}$ & 525 & 0.48 & 215 & 69 \\
\hline 2. & PAIM-2 & $4-\mathrm{OCH}_{3}-\mathrm{C}_{6} \mathrm{H}_{4}-$ & $\mathrm{C}_{32} \mathrm{H}_{23} \mathrm{O}_{4} \mathrm{~N}_{5}$ & 541 & 0.51 & 205 & 72 \\
\hline 3. & PAIM-3 & $2-\mathrm{OCH}_{3}-\mathrm{C}_{6} \mathrm{H}_{4^{-}}$ & $\mathrm{C}_{32} \mathrm{H}_{23} \mathrm{O}_{3} \mathrm{~N}_{5}$ & 525 & 0.42 & 226 & 65 \\
\hline 4. & PAIM-4 & $\mathrm{C}_{10} \mathrm{H}_{7^{-}}$ & $\mathrm{C}_{35} \mathrm{H}_{25} \mathrm{O}_{3} \mathrm{~N}_{5}$ & 564 & 0.47 & 232 & 67 \\
\hline 5. & PAIM-5 & $4-\mathrm{F}-\mathrm{C}_{6} \mathrm{H}_{4}-$ & $\mathrm{C}_{31} \mathrm{H}_{20} \mathrm{O}_{3} \mathrm{~N}_{5} \mathrm{~F}$ & 529 & 0.42 & 198 & 62 \\
\hline 6. & PAIM-6 & 4-Cl- $\mathrm{C}_{6} \mathrm{H}_{4-}$ & $\mathrm{C}_{31} \mathrm{H}_{20} \mathrm{O}_{3} \mathrm{~N}_{5} \mathrm{Cl}$ & 546 & 0.43 & 203 & 65 \\
\hline 7. & PAIM-7 & $\mathrm{C}_{6} \mathrm{H}_{5}^{-}$ & $\mathrm{C}_{31} \mathrm{H}_{21} \mathrm{O}_{3} \mathrm{~N}_{5}$ & 511 & 0.33 & 189 & 66 \\
\hline 8. & PAIM-8 & $3-\mathrm{Cl}-4-\mathrm{F}-\mathrm{C}_{6} \mathrm{H}_{3}-$ & $\mathrm{C}_{31} \mathrm{H}_{19} \mathrm{O}_{3} \mathrm{~N}_{5} \mathrm{FCl}$ & 564 & 0.32 & 211 & 68 \\
\hline 9. & PAIM-9 & $2,5-\mathrm{di}-\mathrm{Cl}-\mathrm{C}_{6} \mathrm{H}_{3}-$ & $\mathrm{C}_{31} \mathrm{H}_{19} \mathrm{O}_{3} \mathrm{~N}_{5} \mathrm{Cl}_{2}$ & 580 & 0.53 & 212 & 69 \\
\hline
\end{tabular}

*Acetone:Benzene: 1:9 
Table 2. TGA data for synthesized imidazolinone derivatives.

\begin{tabular}{|c|c|c|c|c|c|c|}
\hline $\begin{array}{c}\text { Comp. } \\
\text { Code }\end{array}$ & $\begin{array}{l}\text { Amt. } \\
\text { (mg.) }\end{array}$ & $\begin{array}{c}\text { Initial } \\
\text { Decomp. } \\
\text { Temp. } \\
\left({ }^{\circ} \mathrm{C}\right)\end{array}$ & $\begin{array}{l}\text { Decomp. } \\
\text { range } \\
\left({ }^{\circ} \mathrm{C}\right)\end{array}$ & $\begin{array}{c}\% \text { Wt. } \\
\text { loss }\end{array}$ & $\begin{array}{c}\text { Residual Wt. } \\
\text { Loss } \\
\text { (mg.) }\end{array}$ & $\begin{array}{c}\text { Max } \\
\text { Degradt. } \\
\text { Temp. } \\
\left({ }^{\circ} \mathrm{C}\right)\end{array}$ \\
\hline PAIM-1 & 4.0279 & 240 & $240-596$ & 37.7891 & 1.5221 & 596 \\
\hline PAIM-2 & 5.3698 & 239 & $239-581$ & 37.3425 & 2.0052 & 581 \\
\hline PAIM-6 & 5.1339 & 240 & $240-588$ & 38.4844 & 1.9758 & 588 \\
\hline PAIM-4 & 5.6007 & 332 & $332-586$ & 36.2675 & 2.0313 & 586 \\
\hline PAIM-5 & 5.3908 & 252 & $252-596$ & 36.3415 & 1.9591 & 596 \\
\hline PAIM-6 & 4.6280 & 252 & $252-579$ & 33.3523 & 1.6920 & 579 \\
\hline PAIM-7 & 4.1518 & 240 & $240-592$ & 37.3890 & 1.5523 & 592 \\
\hline PAIM-8 & 4.5548 & 212 & $212-594$ & 38.9758 & 1.7753 & 594 \\
\hline PAIM-9 & 4.2117 & 330 & $330-590$ & 40.6477 & 1.7119 & 590 \\
\hline
\end{tabular}

Table 3. The kinetic parameters for all the imidazolinone derivatives for $1^{\text {st }}$ step.

\begin{tabular}{|c|c|c|c|c|}
\hline Comp. code & $\mathbf{n}$ & $\begin{array}{c}\mathbf{E} \\
(\mathbf{k J})\end{array}$ & $\begin{array}{c}\mathbf{A} \\
\mathbf{( S e c}^{-\mathbf{1}} \mathbf{)}\end{array}$ & $\begin{array}{c}\mathbf{\Delta} \mathbf{s}^{\mathbf{0}} \\
\mathbf{( k J}^{-1} \mathbf{)}\end{array}$ \\
\hline PAIM-1 & 6.00 & 239.83 & $1.54 \times 10^{19}$ & 269.25 \\
\hline PAIM-2 & 7.00 & 221.71 & $5.34 \times 10^{17}$ & 241.33 \\
\hline PAIM-6 & 5.00 & 232.22 & $4.10 \times 10^{18}$ & 258.27 \\
\hline PAIM-4 & 8.20 & 34.44 & 4.65 & -87.37 \\
\hline PAIM-5 & 2.50 & 270.21 & $5.37 \times 10^{21}$ & 317.92 \\
\hline PAIM-6 & 15.00 & 100.96 & $3.61 \times 10^{7}$ & 46.72 \\
\hline PAIM-7 & 8.00 & 203.23 & $1.48 \times 10^{16}$ & 211.52 \\
\hline PAIM-8 & 21.00 & 87.76 & $1.71 \times 10^{6}$ & 21.21 \\
\hline PAIM-9 & 7.15 & 46.80 & 36.61 & -70.27 \\
\hline
\end{tabular}

Table 4. The kinetic parameters for all the imidazolinone derivatives for $2^{\text {nd }}$ step.

\begin{tabular}{|c|c|c|c|c|}
\hline Comp. code & $\mathbf{n}$ & $\begin{array}{c}\mathbf{E} \\
(\mathbf{k J})\end{array}$ & $\begin{array}{c}\mathbf{A} \\
\left(\mathbf{S e c}^{-1}\right)\end{array}$ & $\begin{array}{c}\Delta \mathbf{s}^{\mathbf{0}} \\
\left(\mathbf{k J}^{-1}\right)\end{array}$ \\
\hline PAIM-1 & 6.60 & 44.56 & 26.18 & -73.01 \\
\hline PAIM-2 & 6.30 & 61.40 & 415.84 & -50.04 \\
\hline PAIM-6 & 2.50 & 119.72 & $6.77 \times 10^{6}$ & -7.50 \\
\hline PAIM-4 & - & - & - & - \\
\hline PAIM-5 & 6.40 & 42.91 & 19.39 & -75.53 \\
\hline PAIM-6 & 6.0 & 33.81 & 4.31 & -87.95 \\
\hline PAIM-7 & 6.70 & 50.64 & 77.85 & -63.89 \\
\hline PAIM-8 & 5.30 & 92.01 & $6.94 \times 10^{4}$ & -7.37 \\
\hline PAIM-9 & - & - & - & - \\
\hline
\end{tabular}




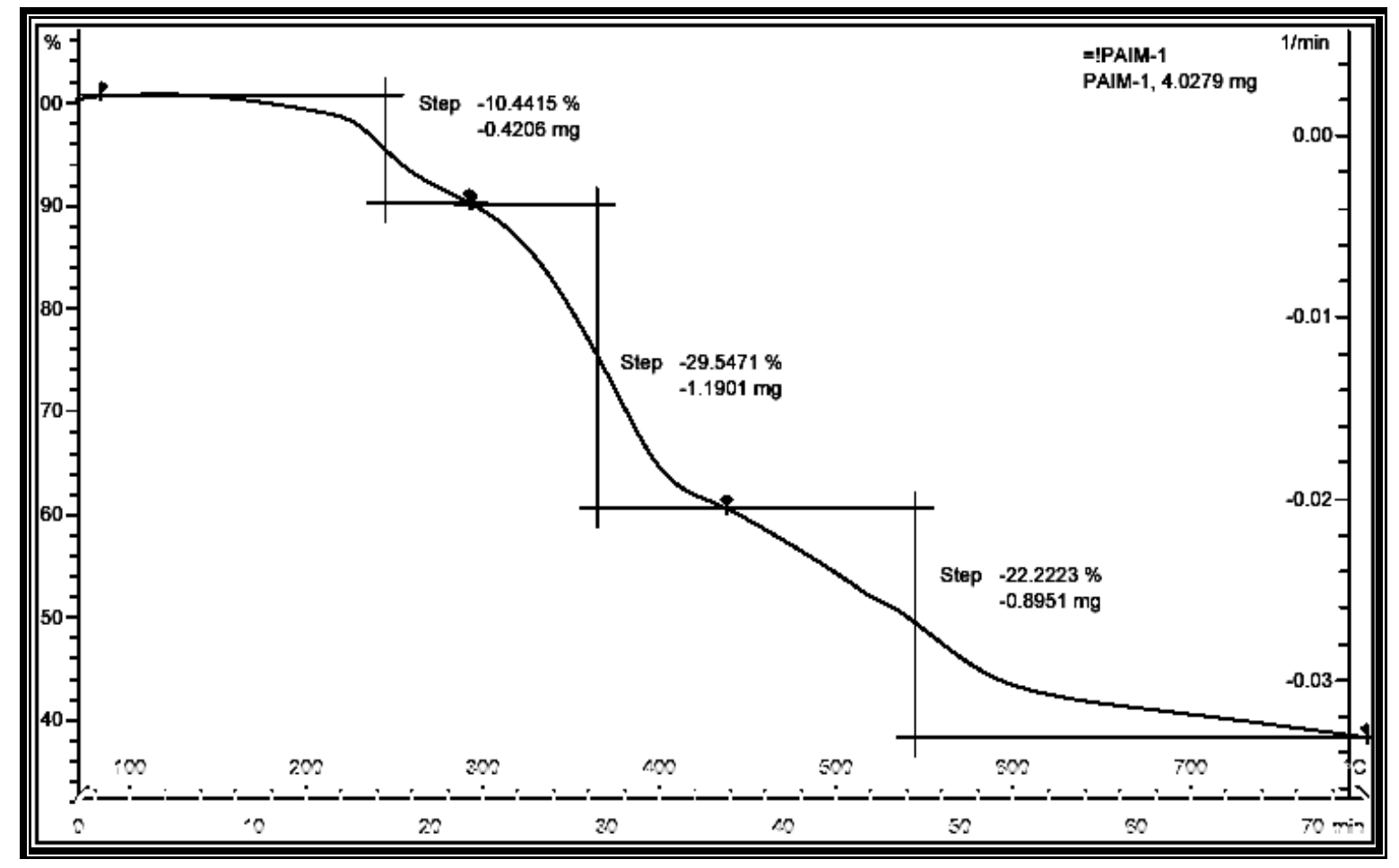

Fig. 1. The TGA graphs of PAIM-1.

\section{References}

[1] M. I. Ayad, A. Mashaly and M. M. Ayad; Thermochim. Acta, 184, 173 (1991).

[2] R. G. J. C. Heijkants, R. V. V. Calck, T. G. V. Tienen, J. H. de Groot; Biomaterials, 26, 4219 (2005).

[3] N. Grioui, K. Halouani, A. Zoulalian and F. Halouani; Thermochim. Acta, 440, 23 (2006).

[4] R. Gupta, C. N. Shanthi, A. K. Mahato, Int. J. Drug Dev. \& Res., 2, 394 (2010)

[5] P. Zhao, W. Liu, Q. Wu, J. Ren, J. Nanomaterials, 2010, 1 (2010)

[6] S. Gaan, L. Mauclaire, P. Rupper, V. Salimova, T. T. Tran, M. Heuberger J. Anal. Appl. Pyrolysis, 90, 33 (2011).

[7] S. S. Guo, X. H. Sun, S. X. Wang, S. Xu, X. Z. Zhao and H. L.W. Chan; Mat. Chem. Phys., 91, 348 (2005).

[8] M. Niculescu, N. Vaszilcin, M. Barzescu, P. Budrugeac, E. Segal; Articol: J.Therm. Ana.Calo., 65, 881 (2001).

[9] O. Ichinose, T. Tanaka, and N. Furuya; Electrochem., 71, 108 (2003).

[10] A. Radecki and M. Weolowski; J. Thermal Anal., 17, 73 (1979).

[11] N. S. Fernandes, M. A. de Silva, R. A. Medes and M. Ionashiro; J. Braz. Chem. Soc., 10, 6 (1999).

[12] D. Giron; J. Thermal Anal. Calorim., 68335 (2002). 
[13] A. F. Barnes, M. J. Hardy, T. J. Lever; J. Thermal Anal. Calorim., 40499 (2007).

[14] A. K. Attia, N. Y. Hassan, A. El-Bayoumi, Samar.G. Abdel-Hamid; Int. J. Current Pharma. Res., 4, 975 (2012).

[15] A. K. Attia, M. M. Abdel-Moety; Adv. Pharma. Bull.,4, 147 ( 2013).

[16] D. A. Anderson and E. S. Freeman; J. Polym. Sci., 54, 253 (1961).

[17] H. H. Horowitz and G. Metzger; Ana. Chem., 35, 1464 (1963).

[18] A. P. Mishra, V. Tiwari, R. Singhal and S. K. Gautam; Thermons, 90 (2002) 